\title{
Should Moroccan Officials Depend on the Workers' Remittances to Finance the Current Account Deficit?
}

\author{
El Mostafa Bentour ${ }^{1}$ \\ ${ }^{1}$ Economic Researcher, Arab Planning Institute, Kuwait \\ Correspondence: El Mostafa Bentour, Economic Researcher, Arab Planning Institute, Kuwait. Tel: \\ 965-2484-3130 or 965-2484-4061 ext.231. E-mail: embentour@gmail.com or mostafa@api.org.kw \\ Received: January 10, 2014 \\ Accepted: January 28, 2014 \\ Online Published: March 25, 2014 \\ doi: 10.5539/ijef.v6n4p157 \\ URL: http://dx.doi.org/10.5539/ijef.v6n4p157
}

\begin{abstract}
The Moroccan economy relies heavily on remittances from abroad to the extent they are far more significant sources of income than others such as foreign direct investments and tourism. To assess the reliability of this external financing source by testing the resilience vis-à-vis the hosting countries, we summarize, in this paper, the impact of the business cycles of major hosting European countries on Moroccan workers' remittances using impulse response functions of a VAR modeling approach. Our findings include, first: the remittances to Morocco and major European countries' GDP are positively correlated (i.e., are procyclical). Second, the recent global financial crisis and the following downturns in countries, such as Italy and Spain, significantly reduced remittances, while remittances from Germany, Netherlands, Belgium and Luxembourg do not seem to be extremely affected.
\end{abstract}

Keywords: remittances, current account balance, impulse response functions

\section{Introduction}

Remittances from Moroccans living abroad are important and significant sources of income. According to the International Organization for Migration report (2006), Morocco is ranked among the top ten receiving countries in terms of remittances. Remittances account for 5 to 9 percent of GDP. Furthermore, receipts from remittances are significantly larger than receipts from other external resources such as foreign direct investments (FDI), tourism, and Official Development Assistance (ODA) (Note 1). The importance of remittance income to Morocco is also reflected in the establishment of the Council for the Moroccan Community Abroad established in 2007 and the ministry of Moroccans Living Abroad.

The impact of remittances on economic growth and social welfare of the concerned families have been largely studied by many researches (Note 2). The effect of business cycle fluctuations, in the host countries, on the amount of remittances varies across studies. Shaun and Gradzka (2007) found that remittances from the U.S. to Latin American countries are relatively insensitive to the U.S. business cycle. Sayan (2007) and Sayan (2010) found that Mexicans' remittances from the U.S. respond positively to the U.S. business cycle, but negatively to the Mexican's business cycle (Note 3), but the income motive (the US economic situation) is dominated by the altruism motive reflected by the Mexican economic situation; i.e., solidarity with relatives in bad economic situation at home. According to Sayan (2007), Turkish remittances behave differently: they do not seem to respond to Germany's business cycle, but they are pro-cyclical to the Turkish's GDP. Remittances pro-cyclicality with respect to the host country's GDP and the counter-cyclicality with respect to the origin country's GDP is supported by Frankel (2010).

Given that Europe remains the main foreign sources of funds to Morocco, we limit our study to the most remitting European countries, which are France, Italy, Spain, Belgium and Luxembourg together, the Netherlands, Germany and the United Kingdom.

The objective of this paper is to study remittances dynamics in Morocco. We ask whether the flow of remittances from Europe can be considered a sustainable source of income to Morocco in the future. The high dependency of Moroccan remittances on the economic conditions in Europe can be destabilized and can limit their historically positive effects on the Moroccan economy. To do so, we use a Vector Auto Regression (VAR) to summarize the data and trace out the impact of the economic conditions in Europe on remittances to Morocco. We also highlight 
the impact of the remittances on the current account imbalances. We found that the business cycle impact on remittances is more pronounced in countries severely hit by the recent financial crisis, such as Italy and Spain, while there is almost no sensitivity of remittances to the business cycle in Netherlands, Germany, Belgium and Luxembourg.

Further, we discuss the reliability of the remittances as a financing source, and the economic implications in time of economic crises on the current account balance. Financial shocks propagate through various channels such as trade balance, FDI, Tourism, Official Development Assistance (ODA) and remittances. We found that remittances exert sizable and significant impacts on the current account. Ad-hoc relationships show an enhancement of the Current Account Balance in the short and long run when remittances increase. The short run effect of remittances is much bigger than the long run marginal effect and highly overcome the effect of net exports on the current account.

Next, we present data and discuss the importance of remittances compared to other external financial flows. The third section displays methodology. The fourth section displays the empirical evidence and the fifth one concludes.

\section{Data, Trends and Analysis}

The purpose of the paper is to identify the macroeconomic linkages that may govern the Moroccan remittances inflows from the European Union with the main economic aggregates of the host countries, especially with Gross Domestic Product. We seek presumable connections between each series of remittances and GDP of major sending countries of the European Union. The distribution share of remittances by country, in Table 1, allows to contain this group on seven important countries in terms of workers' remittances to Morocco, namely France, Italy, Spain, Belgium and Luxembourg together, the Netherlands, Germany and the United Kingdom. We also analyzed the impact of remittances on the current account.

Table 1. Distribution of remittances by European Union hosting countries (\% of total)

\begin{tabular}{lcccc}
\hline & 1997 & 2002 & 2007 & Averages 1997-2007 \\
\hline France & 61.2 & 51.5 & 48.3 & 50.6 \\
Italy & 10.6 & 13.2 & 13.9 & 14 \\
Spain & 3.8 & 7 & 17.5 & 10.8 \\
Belgium + Luxembourg & 8.3 & 7.4 & 4.8 & 6.3 \\
Netherlands & 5.2 & 7.5 & 4.8 & 6.2 \\
Germany & 5.7 & 4.8 & 3.8 & 4.6 \\
United Kingdom & 2.1 & 4.6 & 4.4 & 4.3 \\
Switzerland & 1.5 & 2.4 & 1.4 & 1.9 \\
Other European Countries & 1.5 & 1.7 & 1.1 & 1.4 \\
\hline
\end{tabular}

\subsection{Data and Sources Description}

As far as the database used in the paper, we actually use two main sources. For the national data on remittances and the balance of payments, our source is the exchange office "offices des changes", (http://www.oc.gov.ma). As for the European Union countries data, the source is the World Development Indicators database of the World Bank. A number of data clarifications are needed in this respect:

$\checkmark$ The amount of worker remittances, available in time series over 1982-2010, for the total, the total of European Union bloc and by important sender countries, in current dirham from the source "Office des Changes", deflated by the consumer price index of base year 2005, then converted to the United States $\$$.

$\checkmark$ GDPs time series of the EU countries is drawn from the World Development Indicators of the World Bank, in PPP constant US \$, base year 2005.

$\checkmark$ In addition, other aggregates for inflation in the studied EU countries, the unemployment rate were tested. However, they failed to find out clear relationships with remittances. The data are also from the WDI database of the World Bank.

$\checkmark$ The components of the Moroccan current account balance and other aggregates of the balance of payments are obtained from the source of "Office des Changes".

$\checkmark$ The data on remittances by main used sending channels (Banknotes, Bank transfers, postal transfers and 
others) and data on Nets Foreign Assets are from the Central Bank of Morocco (http://www.bkam.ma).

\subsection{The Importance of Remittances}

Using officially recorded flows on the actual amount of remittances (Note 4), we show that they are enormous and continue to grow especially in the past recent decade. Figure 1 shows the evolution, in level and growth rate, of the total remittances over the period 1981-2010. The graph displays relatively stable growth rate of remittances in the second and third decade, comparing to the first decade of the period, except in the year 2001, where the remittances jumped to its historical increase (over 60\%). To effects of such an increase can be traced: first, the "Euro effect". Moroccans abroad who had accumulated large sums in various European currencies were forced not to justify the origin of the funds to the taxing authorities. Others may not be welcomed with great confidence the new currency. Second, "The 11 September effect". Large amounts of remittances were recorded from countries outside the euro zone to probably insure their security in the home country (Note 5).

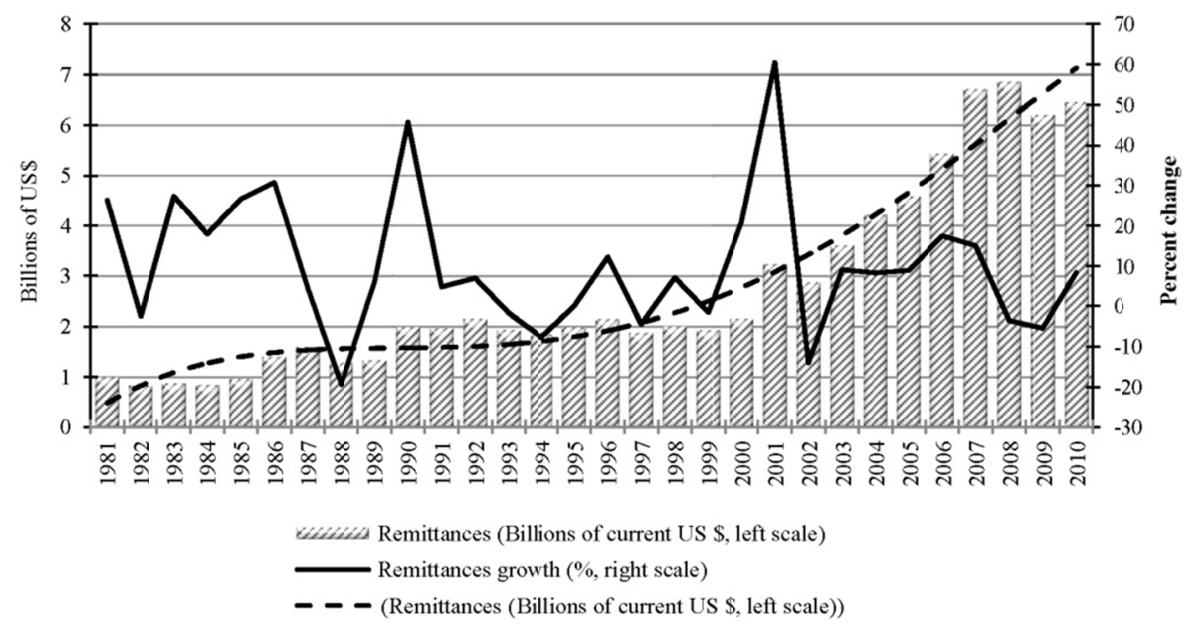

Figure 1. Trends of total remittances to Morocco in level and growth rate

The subsequent increase over time is mainly due to a number of factors such as: seniority in the job, increasing skilled migration, the development of official channels used to send money home; especially increasing of the banking sector role as highlighted in Table 2 .

Table 2. Remittances' trends by types of official sending channels (percent of total)

\begin{tabular}{lcccccc}
\hline & 1980 & 1985 & 1990 & 1995 & 2000 & 2005 \\
\hline Banknotes & $5.00 \%$ & $9.30 \%$ & $9.50 \%$ & $15.50 \%$ & $29.60 \%$ & $27.70 \%$ \\
Bank transfers & $48.20 \%$ & $47.20 \%$ & $70.80 \%$ & $66.50 \%$ & $57.10 \%$ & $68.70 \%$ \\
Postal transfers & $46.70 \%$ & $43.50 \%$ & $19.70 \%$ & $18.00 \%$ & $13.30 \%$ & $3.60 \%$ \\
\hline
\end{tabular}

Source: Central Bank of Morocco.

Remittances have the most important share in contributing to the financing of the current account deficit vis-à-vis other sources of funding. Figure 2 illustrates, for the period 1997-2007, the net flows components of the current account balance as a share of GDP namely; net private current transfers (mainly remittances) (Note 6), net investment income and loans, net exports (trade balance) and net public transfers. It is clear that the two major components are trade balance and private transfers and the later largely offset the first one. This leads to record surpluses of the current account over the period 2001-2006, despite the continuing growing trade deficit in this period due especially to soaring energy and food prices. 


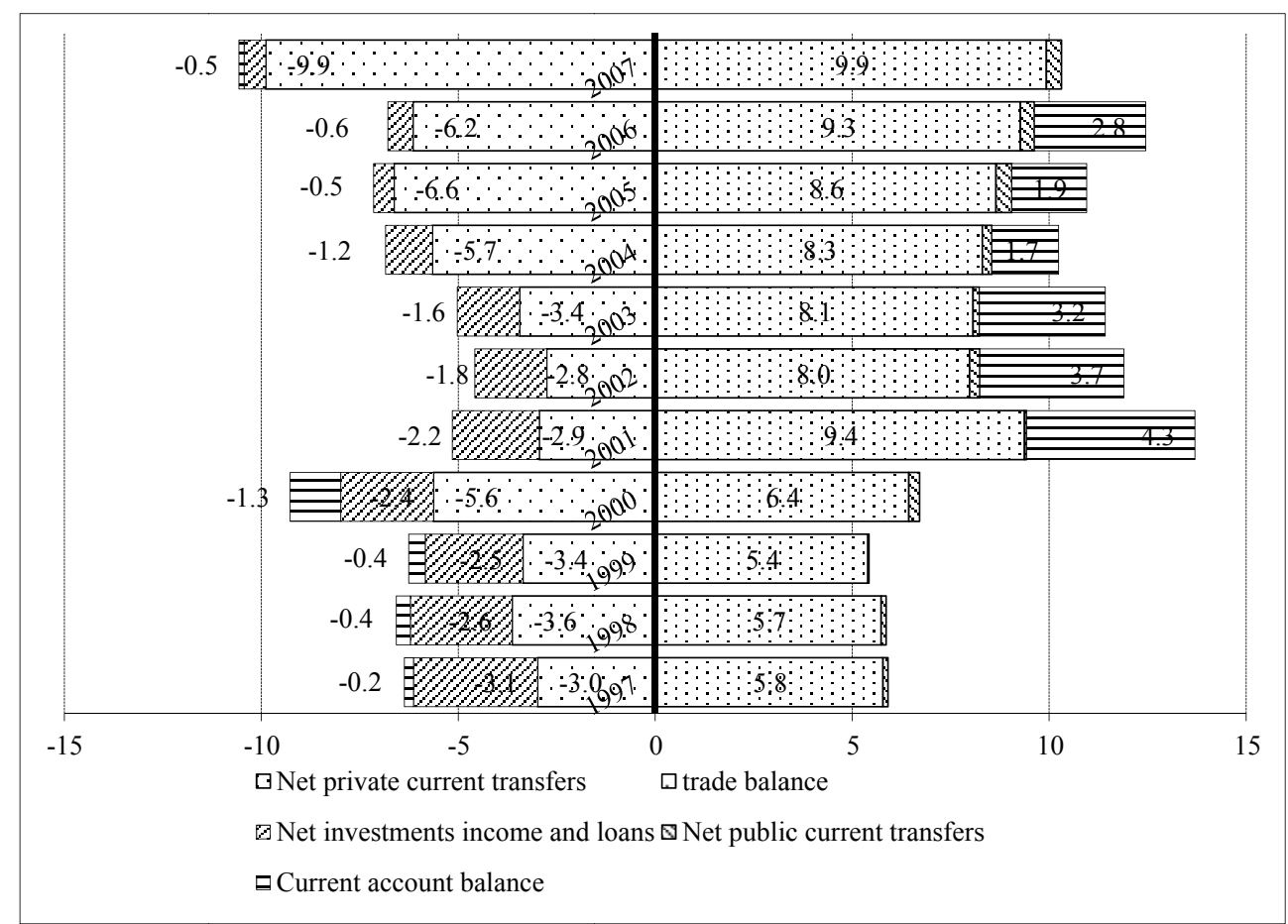

Figure 2. Evolution of net components of the current account as percent of GDP

To compare remittances to other economic aggregates and other external financing sources, Figure 3 shows the shares of remittances to GDP, household disposable income, investment, export, import, FDI (Note 7), tourism receipts, Public debt and ODA. As shows, the remittances flows overshadow the role of the other external financial flows, namely, FDI, ODA, public debt and tourism. It accounts in the average, over the period 19972007, about $7 \%$ of GDP, $10 \%$ of household disposable income, $26 \%$ of Gross Fixed Capital Formation, $20 \%$ of imports, $23 \%$ of exports, $108 \%$ of tourism receipts, $312 \%$ of FDI, $537 \%$ of ODA, $183 \%$ of total public debt and almost ten times external debt over the period 1997-2007. Thus, remittances are the second largest source of foreign reserves behind exports in Morocco.

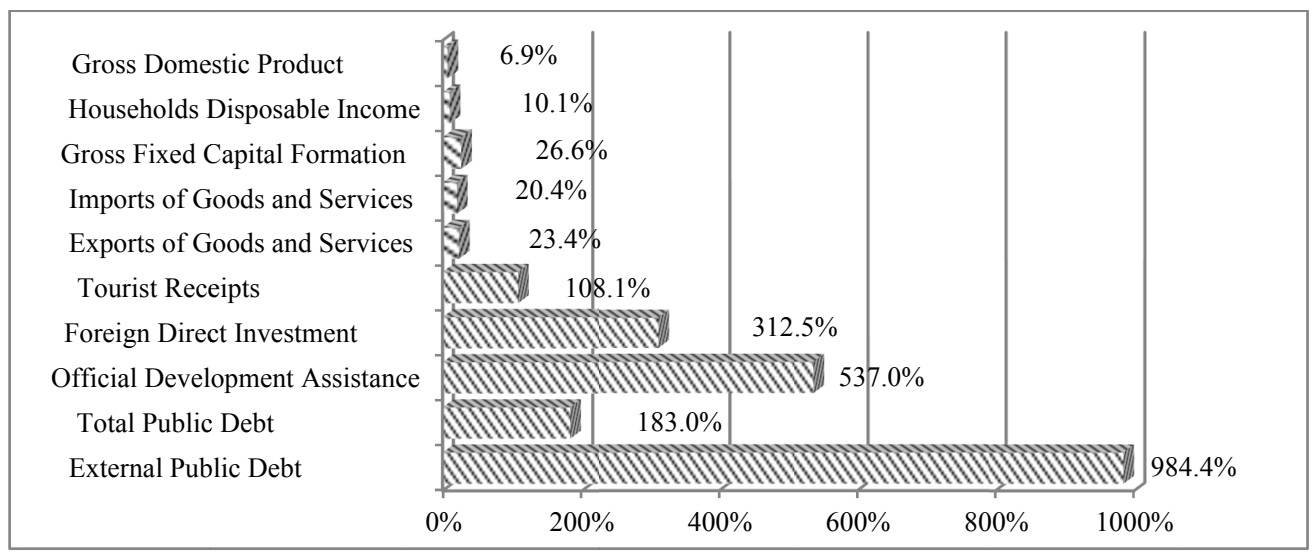

Figure 3. Importance of remittances as ratios of some economic aggregates and other foreign funding sources

By geographical repartition (Figure 4), remittances to Morocco come mainly from three main regions: Europe, North America and the Gulf countries. However, due to its geographical proximity, historical ties and colonial economic influence, Western Europe has always constituted the main destination of Moroccan migrants. Thus, it dominates the other parts of the world in terms of the amounts transferred to the home country. Indeed, the share of transfers from this region reached $88.9 \%$ on average over the period 1997-2007, followed by the United States and Canada with 5.8\% and the Gulf countries with $5.1 \%$ average over the same period. The remaining 
share is insignificant $(0.2 \%)$ and comes from other countries such as the Maghreb countries (Libya, Tunisia). The importance of transfers from European countries then justifies the choice of the sample on which this study will focus.

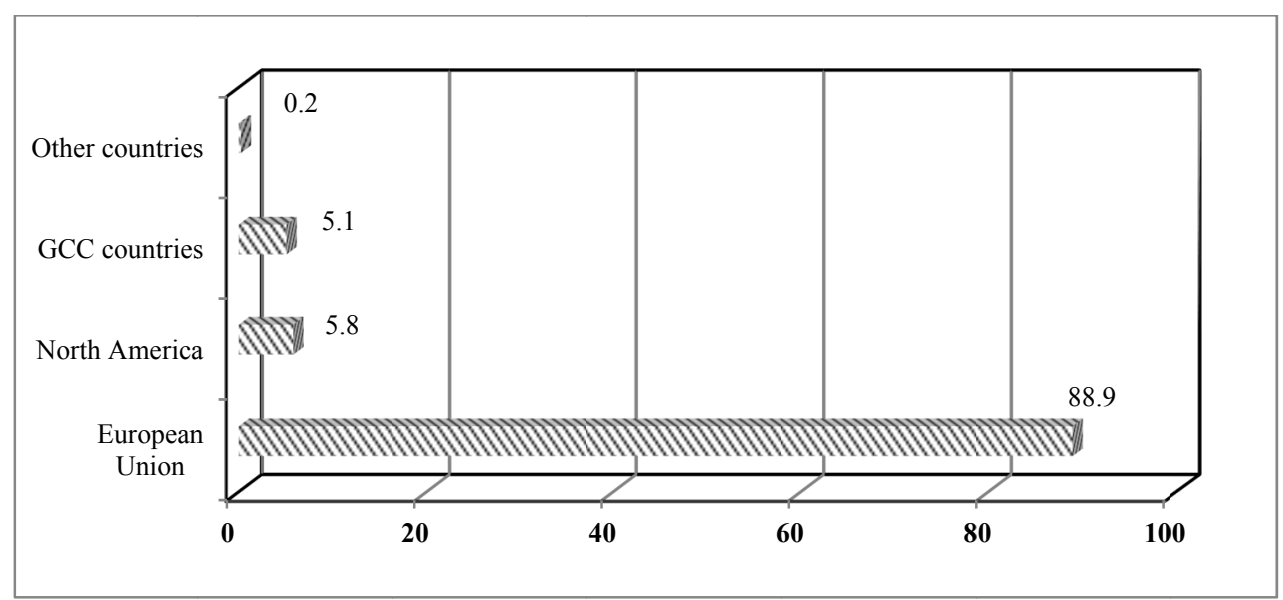

Figure 4. Averages' shares of remittances to Morocco by region (in \%, over 1997-2007)

Considering the European Union sample countries, Table 1 in section 2, shows that shares are dominated by remittances sent from France with 50.6\% on average over the period 1997-2007, followed by Italy and Spain with $14 \%$ and $10.8 \%$. Nearly $21.4 \%$ remaining is from the Netherlands, Belgium and Luxembourg, Germany and the United Kingdom. Our sample contains the whole part of remittances coming from European Union countries (the share on the total of European Union is $96.8 \%$ ). We then cover about $86 \%$ of remittances coming from the entire world (Note 8).

\section{Methodology}

To assess the linkages between remittances and the GDP of European Union countries, we use the Vector Auto-Regression (VAR) methodology. We especially exploit the impulse response functions displayed by VAR modeling to estimate the direction of the impact, the relative magnitude and delays of response on remittances due to the shocks on European countries' GDPs.

\subsection{VAR Methodology}

Classical econometric modeling based on the estimation of structural equations has been subject to much criticism, particularly from Sims (1980). This brought the VAR models as an alternative now quite familiar to practitioners of economic analysis and forecasts. These models can be used to characterize the stylized facts of the business cycle, study multipliers generated by a shock on the error term of the process (known also as innovation) and identify structural shocks as described by the economic theory. The range of specifications of these models covers various possible representations of the studied phenomena.

Standard VAR models are presented in reduced forms based on the assumption that the evolution of the economy is well approximated by a description of the dynamic behavior of a vector with $\boldsymbol{k}$ linearly dependent variables to their past. Simplified representation of such models is as follows:

$$
Y_{t}=C+A_{1} Y_{t-1}+A_{2} Y_{t-2}+\ldots+A_{p} Y_{t-p}+\zeta_{t}
$$

Where $Y_{t}, C$ and $\zeta_{t}$ are $k \times 1$ vectors of respectively endogenous variables, constant terms and error terms. $A_{j}$ is a $k \times k$ matrix of coefficients to be estimated for every $j=1, \ldots, p$. Errors $\zeta_{t}$ can be correlated to current values (period t) but are uncorrelated with their past values and are uncorrelated with all other variables in the right-hand side of the VAR system.

Since only lagged values of the endogenous variables appear on the right side of each equation, there is no problem of simultaneity, and Ordinary Least Square (OLS) is an appropriate estimation technique.

The weaknesses of the VAR are that they need larger time series for a growing number of variables and or the presence of great number of lags. However, this problem is overcome in our case since we only have two 
variables for each country and our lags are shorter (we found usually one lag for the most VAR models, for some the maximum found is 2 lags). Our first sample is 30 observations (1982-2011) and the degree of freedom is 26 , making it possible to estimate under the properties of the Central Limit Theorem. The second drawback of the VAR methodology in its standard form; the reduced form, is that you can't clearly set up relationships derived from an economic theory; the VAR are said a-theoretical process. For our case, this is also not a concern, since there is no explicit economic theory relying remittances to GDPs of the hosting countries.

The choice of variables involved in a VAR model is dictated by causality linkages that may exist between them. There should be correlations (Note 9) between variables of the VAR but correlation does not mean causation. The most used causality tests are those pioneered by Sims and Granger. Furthermore, the system VAR must be stable; the endogenous variables must be stationary. In fact, this property of invariance of statistical characteristics of the process for all translations in time is mandatory to make it possible to identify the Data Generating Process of the variables. Impulse response functions for a given shock and causality tests are best identified using differenced data but without over-differencing the series (Ashley, 2009). The stationary properties are checked by the most used tests of Dickey-Fuller and or Phillips-Peron. Thus our models should be written in differences or differentiated logarithm of the variables in case of integrated variables. The number of lags $\boldsymbol{p}$ is obtained by tests of information criteria such as Akaike Information Criterion (AIC) and Schwartz Criterion (SC).

The impulse response function measures the impact of the $i^{\text {th }}$ variable in the VAR system following a shock on the standard error of another variable of the system. Considering a Wold decomposition for a $\operatorname{VAR}(\mathrm{p})$ in equation (1):

$$
Y_{t}=A(L) \zeta_{t}=\sum_{i=0}^{\infty} A_{i} \zeta_{t-i}
$$

We derive the following matrices:

$$
\frac{\partial Y_{t}}{\partial \zeta_{t-j}}=A_{j} \text { or } \frac{\partial Y_{t+j}}{\partial \zeta_{t}}=A_{j}
$$

The row $i$ and column $\boldsymbol{k}$ of the matrices $A_{j}$ identifies the effect of a unit increase in the $k^{\text {th }}$ variable's innovation at time $t$ (respectively $t+j$ ) for the value of the $i^{\text {th }}$ variable at time $t-j$ (respectively $t$ ) holding all other innovations at all times constant.

In practice, the $\operatorname{cov}\left(\zeta_{t}\right)=\Sigma$ could be non-diagonal; this is because errors are usually correlated in the real world. It is impossible to shock one variable with other variables held constant. Some kind of transformation is needed. Econometricians developed some methods and the most popular is the Cholesky decomposition.

\subsection{Remittances' Component in the Current Account Balance}

To study the impact of remittances on the current account balance, we use an analytical approach and empirical regressions of the current account balance $(\mathrm{CAB})$ on net inflows of remittances. This is based on the definition of the current account identity:

$$
C A B_{t}=N X_{t}+N Y_{t}+N C T_{t}
$$

Where: $N X$ is net export or trade balance of goods and services (exports-imports), $N Y$ is net income from abroad and $N C T$ is a net current transfer. This later is split to private transfers (NPT) and public or government transfers $(N G T)$ :

$$
N C T_{t}=N P T_{t}+N G T_{t}
$$

Net private transfers are worker remittances $(R E M)$ and other private transfers $(O P T)$

$$
N P T_{t}=R E M_{t}+O P T_{t}
$$

In the case of Morocco, remittances are the dominant component while other private transfers are about $5 \%$ to $9 \%$ in the total.

From the previous identities, the current account balance is rewritten as:

$$
C A B_{t}=N X_{t}+N Y_{t}+R E M_{t}+N G T_{t}+O P T_{t}
$$

The impact of remittances is transmitted directly to the current account balance. Differencing the equation (7) and reporting to $C A B_{t-1}$, we get: 


$$
g_{C A B_{t}}=g_{N X_{t}} \cdot s_{N X_{t}}+g_{N Y_{t}} \cdot s_{N Y_{t}}+g_{R E M_{t}} \cdot s_{R E M_{t}}+g_{N G T_{t}} \cdot s_{N G T_{t}}+g_{O P T_{t}} \cdot s_{O P T_{t}}
$$

Where $g_{X_{t}}$ is; the growth rate of $X_{t} ; X \in\{C A B, N X, N Y, R E M, N G T, O P T\}$ and $s_{X_{t}}$ is the share of $X_{t}$ to $C A B_{t-1}$. The product $g_{X_{t}} \cdot s_{X_{t}}$ defines the contribution of the component $X_{t}$ to the growth rate of the current account balance. Equation (8) is used for analysis based on the components' contributions to the current account growth.

A current account balance could be negative (deficit) or positive (surplus). An interpretation of the current account growth rate could be misleading; when for example the current account is in deficit for two consecutive years, $C A B_{t-1} \leq C A B_{t} \leq 0$, the growth rate is negative but there is an improvement (reduced deficit) in the current account between the two years. However, in case of an increasing deficit, the growth rate is positive. Also there is a puzzling interpretation when we jump from surplus to deficit and vice versa. In times of successive surpluses, an amelioration in the current account means positive growth rate and deterioration means negative growth rate. For regression purposes, and to avoid misleading interpretation in the growth rate of the $\mathrm{CAB}$, I prefer to use the cumulative CAB; the Net Foreign Assets aggregate.

In the classical approach of the balance of payments, change in Net Foreign Assets (NFA) equates the Current Account Balance (CAB):

$$
\triangle N F A_{t}=C A B_{t}
$$

However, it is revealed that there must be differences between both sides of the equation (9) due to differences in assets prices and exchange rate fluctuations. These differences are called valuation effects (VAE) (Note 10):

\section{Empirical Evidence}

$$
\Delta N F A_{t}=C A B_{t}+V A E_{t}
$$

Economic growth measured by the percent change of the Gross Domestic Product (GDP) is a primary indicator used to gauge the healthy path of a productive economy. In time of declining or recession, the economic activity is contracting in many productive sectors leading to cost reductions and layoffs by companies or sometimes austerity measures by governments. Therefore, household incomes are reduced. Migrant workers income is also affected and may be remittances should follow. To assess whether remittances are affected by the changing income in the host countries, we opt for studying linkages between GDP (Note 11) of the host countries and remittances paid to the Moroccan migrants. Linkages are best described by a VAR model rather than any other ad-hoc relationship since there is no explicit economic theory governing them.

Explicitly, GDP and remittances (REM) are related by the log-linear following system:

$$
\left\{\begin{array}{l}
d \log \left(\operatorname{REM}_{t}\right)=c_{1}+\sum_{j=1}^{p} \alpha_{1 j} d \log \left(\operatorname{REM}_{t-j}\right)+\sum_{j=1}^{p} \beta_{1 j} d \log \left(G D P_{t-j}\right)+\varepsilon_{1 t} \\
d \log \left(G D P_{t}\right)=c_{2}+\sum_{j=1}^{p} \alpha_{2 j} d \log \left(\operatorname{REM}_{t-j}\right)+\sum_{j=1}^{p} \beta_{2 j} d \log \left(G D P_{t-j}\right)+\varepsilon_{2 t}
\end{array}\right.
$$

Where subscript $\mathrm{t}$ designs time, $c_{1}$ and $c_{2}$ are constant terms, $\alpha_{i j}$ and $\beta_{i j}$ are associated coefficients to lagged terms, $p$ is the lag order determined by lag selection criteria and, $\varepsilon_{l t}$ and $\varepsilon_{2 t}$ are error terms.

Table 3. Correlation matrices, in levels and growth rates (dlog), between remittances to Morocco and GDPs of the major European sending countries

\begin{tabular}{ccccccccc}
\hline & $\begin{array}{c}\text { European } \\
\text { Union }\end{array}$ & France & Italy & Spain & Germany & $\begin{array}{c}\text { United } \\
\text { Kingdom }\end{array}$ & Netherlands & $\begin{array}{c}\text { Belgium \& } \\
\text { Luxembourg }\end{array}$ \\
\hline Samples & & & \multicolumn{7}{c}{ Variables in levels } \\
$1982-2011$ & 0.94 & 0.56 & 0.9 & 0.89 & 0.67 & 0.92 & 0.37 & 0.74 \\
$1990-2011$ & 0.93 & 0.63 & 0.94 & 0.94 & 0.7 & 0.95 & 0.28 & 0.71 \\
2000-2011 & 0.97 & 0.98 & 0.77 & 0.98 & 0.83 & 0.84 & 0.31 & 0.82 \\
Samples & & & \multicolumn{7}{c}{ Variables in differences (dlog) } & & \\
$1982-2011$ & 0.16 & 0.11 & 0.17 & 0.43 & 0 & 0.41 & 0.14 & -0.14 \\
$1990-2011$ & 0.22 & 0.3 & 0.29 & 0.41 & 0.09 & 0.52 & 0.23 & 0.07 \\
2000-2011 & 0.52 & 0.41 & 0.42 & 0.77 & 0.02 & 0.61 & 0.4 & -0.02 \\
\hline
\end{tabular}


Table 3 shows the correlation matrices between Remittances and GDP in levels and growth rates (log and dlog variables) over the following period samples: 1982-2011, 1990-2011 and 2000-2011.

There are high positive correlations in levels, except for Netherlands where the correlations are moderate. The most important thing is the presence of significant positive correlations also in growth rates for all countries except Germany and Belgium+Luxembourg where correlations are practically zero. We also note that correlations are higher in recent periods than old ones. This means that remittances are most influenced by host countries' GDPs nowadays than previously. We use Dickey-Fuller test for detecting unit root of the series. The result, summarized in table 3 , is that all series are first order integrated. The causality tests performed by Granger test show an impact of the GDP on remittances and the opposite way does not hold (Table 4).

Table 4. Pairwise Granger Causality tests

\begin{tabular}{llcc}
\hline \multirow{2}{*}{ France } & \multicolumn{1}{c}{ Null Hypothesis } & F-Statistic & Probability \\
& GDP does not Granger Cause Remittances & 5.336 & 0.03 \\
Italy & Remittances does not Granger Cause GDP & 1.917 & 0.179 \\
& GDP does not Granger Cause Remittances & 4.567 & 0.043 \\
Spain & Remittances does not Granger Cause GDP & 1.114 & 0.302 \\
& GDP does not Granger Cause Remittances & 3.627 & 0.069 \\
United Kindgom & Remittances does not Granger Cause GDP & 0.005 & 0.946 \\
& GDP does not Granger Cause Remittances & 5.808 & 0.024 \\
Germany & Remittances does not Granger Cause GDP & 0.535 & 0.472 \\
& GDP does not Granger Cause Remittances & 4.48 & 0.045 \\
Netherlands & Remittances does not Granger Cause GDP & 0.481 & 0.495 \\
& GDP does not Granger Cause Remittances & 3.043 & 0.066 \\
Belgium+Luxembourg & Remittances does not Granger Cause GDP & 0.633 & 0.539 \\
& GDP does not Granger Cause Remittances & 8.836 & 0.007 \\
European Union & Remittances does not Granger Cause GDP & 1.172 & 0.29 \\
& GDP does not Granger Cause Remittances & 8.634 & 0.007 \\
& Remittances does not Granger Cause GDP & 2.833 & 0.104 \\
\hline
\end{tabular}

We also studied the cointegration relationship for each VAR variables to test whether to choose a VAR specification or a Vector Error Correction (VEC) specification. We found that there is no cointegration between the components of the identified VAR models except for the case of Spain. Table 5 displays the selected VAR Models (and VECM for the case of Spain) and their characteristics (number of lags, integration order).

Table 5. Selected VAR models of remittances and GDP of the remitting countries

\begin{tabular}{lcccc}
\hline & Lags $\mathrm{p}$ & Crtiteria* & Cointegration & $\operatorname{VAR}(\mathrm{p}, \mathrm{q}), \operatorname{VECM}(\mathrm{p}, \mathrm{q}) * *$ \\
\hline European Union & 1 & AIC, SC, HQ, FPE & No & $\operatorname{VAR}(1,1)$ \\
France & 1 & AIC, SC, HQ, FPE & No & $\operatorname{VAR}(1,1)$ \\
Italy & $2 / 1$ & AIC, FPE / SC, HQ & No & $\operatorname{VAR}(2,1) / \operatorname{VAR}(1,1)$ \\
Spain & 1 & AIC, SC, HQ, FPE & Yes & $\operatorname{VECM}(1,1)$ \\
United Kingdom & $2 / 1$ & AIC, FPE, HQ / SC & No & $\operatorname{VAR}(2,1) / \operatorname{VAR}(1,1)$ \\
Germany & 1 & AIC, SC, HQ, FPE & No & $\operatorname{VAR}(1,1)$ \\
Netherlands & $2 / 1$ & AIC, FPE, HQ / SC & No \\
Belgium+Luxembourg & 1 & AIC, SC, HQ, FPE & No & $\operatorname{VAR}(2,1) / \operatorname{VAR}(1,1)$ \\
* Criteria are Akaike Information (AIC), Schwartz (SC), Hannan-Quinn (HQ) and Final Predictor Error (FPE). &
\end{tabular}

Finally, Figures 5-1 and 5-2 present the Cholesky response functions (Note 12) of remittances due to a shock on innovations of the GDPs term equal to a standard deviation unit. We estimate for each country, the impact over two periods: 1982-2011 and 1990-2011 to confirm the observation made about the increasing correlations over the time between GDP and remittances. We first note that for all countries, total remittances sent from European Union and from countries of the sample are pro-cyclical to GDP over the two periods, and the effect is much 
bigger for the sub sample 1990-2011 than the whole period. All impacts are positive as shown in all charts. The effect is more pronounced in Spain, Italy and United Kingdom. The effect is less pronounced in Germany and Netherlands and practically non significant for Belgium+Luxembourg in accordance with the absence of short run correlations revealed in table 3 . We also note that, the magnitude, time of maximum response and deadline of declining differ across countries. For example, the response function is at its maximum of 0.03 in the second year for the case of France. The shock takes about three years to fade away. However, response function for remittances from Italy to its GDP is in its maximum in the second year and reaches around 0.15 in the second sample. The effect in the United Kingdom VAR takes three to four years to fade away. The case of Spain is a VECM where the long run is present in the shock and thus the chart response function embodied the long run effect. The permanent effect is attained at around the sixth year and is about 0.25 for the period 1982-2011 and 0.32 for the sample 1990-2011.
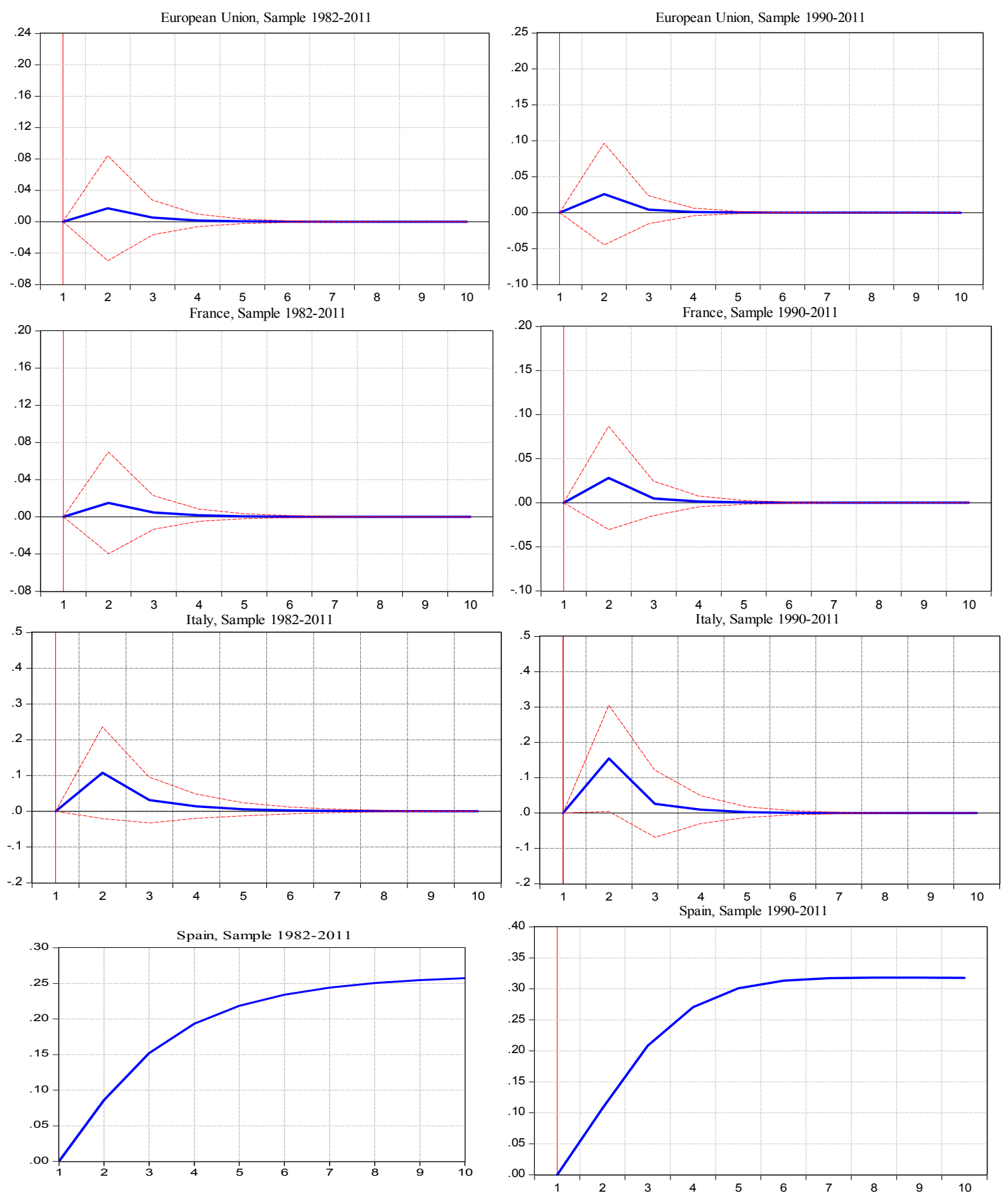

Figure 5-1. Response functions of Moroccan migrant remittances to GDPs' host countries 

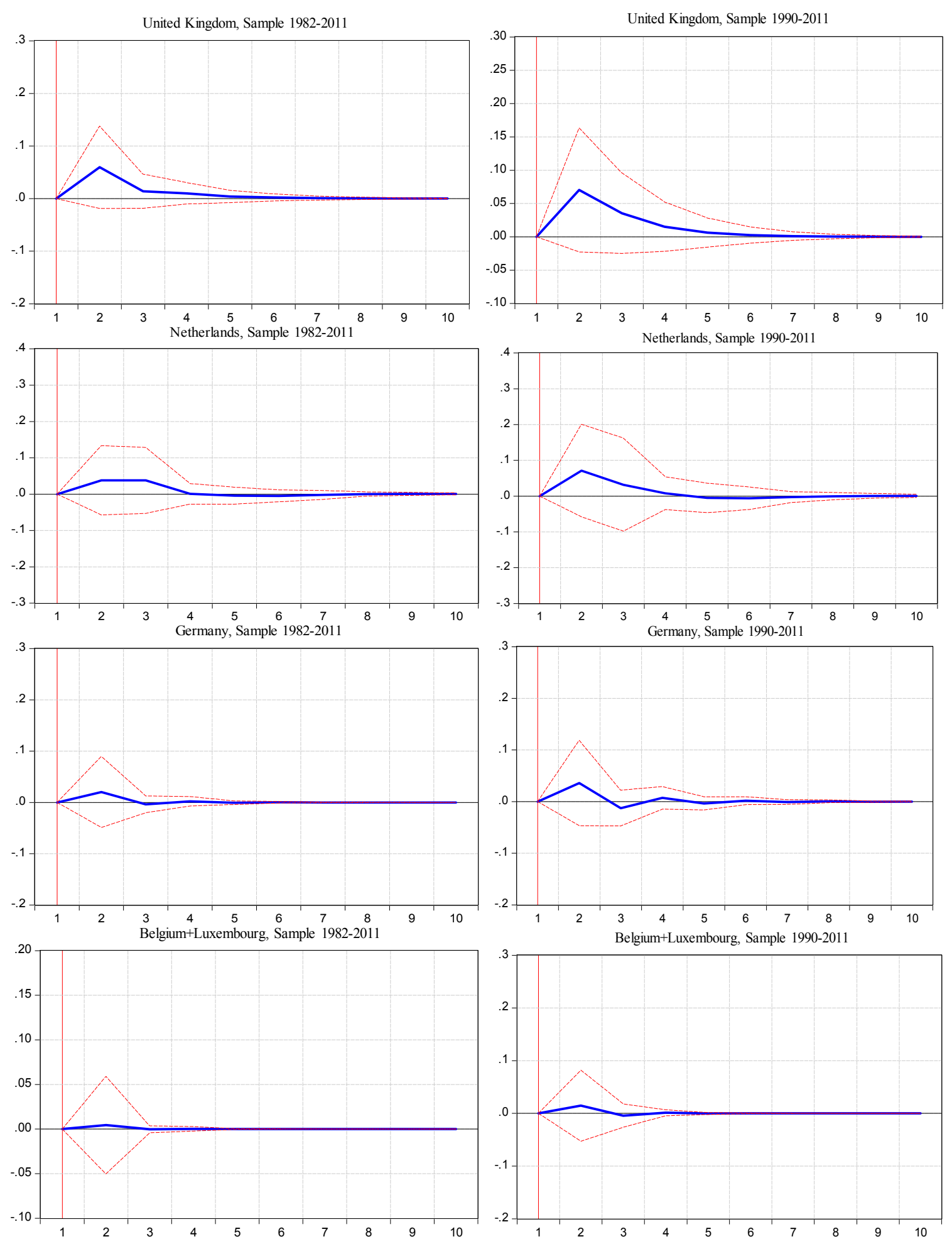

Figure 5-2. Response functions of Moroccan migrant remittances to GDPs' host countries

Now that we confirmed the pro-cyclicality of migrants' remittances to the most host countries' GDPs, we derive some empirical relationships from the equations in the precedent section linking the current account balance to remittances. The goal is to estimate the impact of remittances and their underlying role in smoothing the current account. Estimating the elasticity of remittances to current account balance, I run a regression linking logarithm of remittances as independent variable to logarithm of net foreign assets (Note 13) over the period 1990-2011. We find that the two variables are co-integrated and an error correction model is established. Since we use net foreign assets and not change in net foreign asset, the estimated impact resume on this regression an effect on the 
accumulated current account.

In the Error Correction Model (ECM), we could estimate the long run relationship and recuperate the residuals to be introduced in the ECM or estimate in one step the model:

$$
d \log \left(N F A_{t}\right)=c+\alpha \cdot d \log \left(R E M_{t}\right)+\lambda \cdot\left[\log \left(N F A_{t-1}\right)-\beta \cdot \log \left(R E M_{t-1}\right)\right]+\varepsilon_{t}
$$

Where: NFA and REM are respectively Net Foreign Assets and Remittances, $t$ is time, $\lambda$ is the speed of convergence to the long run equilibrium. Putting $\eta=-\lambda \beta$ we estimate the following equation and presents the output below:

$$
d \log \left(N F A_{t}\right)=c+\alpha \cdot d \log \left(R E M_{t}\right)+\lambda \cdot \log \left(N F A_{t-1}\right)+\eta \cdot \log \left(R E M_{t-1}\right)+\varepsilon_{t}
$$

Table 6. Data

\begin{tabular}{llll}
\hline & Coefficient value & Standard Error & P-value \\
\hline $\boldsymbol{\alpha}$ & 0.752 & 0.232 & 0.005 \\
$\boldsymbol{\beta}$ & -0.263 & 0.072 & 0.002 \\
$\boldsymbol{\eta}$ & 0.419 & 0.107 & 0.001 \\
\hline
\end{tabular}

Sample: $1990-2011, \mathrm{DW}=2.052 ; \mathrm{SE}=0.131 ; \mathrm{R} 2 \mathrm{adj} .=0.461$.

The short run elasticity is about $\boldsymbol{\alpha}=0.75$. A $10 \%$ increase in remittances should, ceteris paribus, increase the cumulative current account by $7.5 \%$. The speed of convergence (1-inertia) is about $1 / 4,(\beta=-0.26)$, and the long run term effect is $\beta=\frac{-\eta}{\lambda} \cong 1.6$.

Using data on the current account over 1990-2011, Figures 6 and 7 show that remittances and trade deficit (net exports) are the major components of the change in Net Foreign Assets. The sum of other components (net income from abroad, public transfers, other private transfers than remittances and valuation effects) considered residual is small. On average over 1990-2011, change in NFA is about $0.8 \%$ with remittances component mean equal $7 \%$ and trade deficit mean equal $-6.1 \%$. The residual term is about $0.1 \%$ over the two decades.

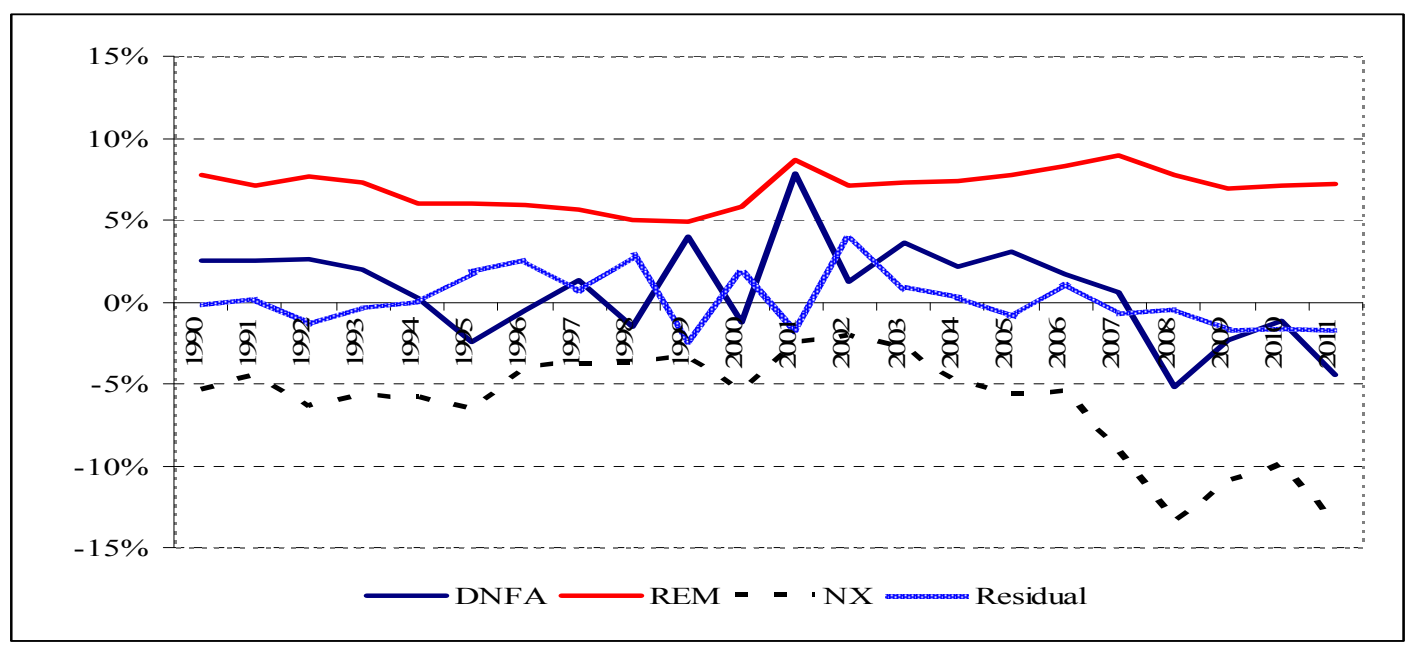

Figure 6. Trends of change in NFA, Net Exports, remittances and residual (as \% of GDP) 


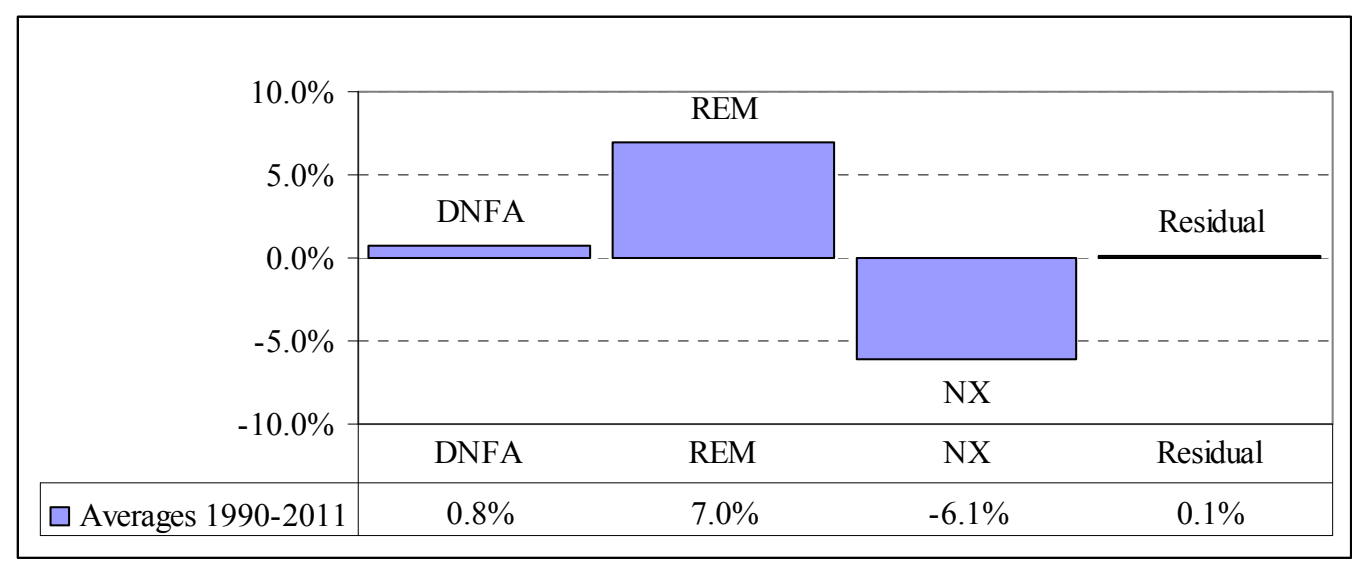

Figure 7. Averages over 1990-2011 of change in NFA, remittances and net exports as \% of GDP

Next, to account for the second major component; net export, in term of contribution to the current account, I estimate the following model (form ECM) (note 14) where we link change in net foreign assets to the net exports of goods and services and net inflows of remittances and presents the output in the following table:

$$
d\left(\Delta N F A_{t}\right)=c+\alpha \cdot d\left(R E M_{t}\right)+\beta \cdot d\left(N E X_{t}\right)+\lambda \cdot \Delta N F A_{t-1}+\eta \cdot R E M_{t-1}+\delta \cdot N E X_{t-1}+\varepsilon_{t}
$$

Table 7. Data

\begin{tabular}{llll}
\hline & Coefficient value & Standard Error & P-value \\
\hline $\boldsymbol{\alpha}$ & 1.522 & 0.298 & 0.0000 \\
$\boldsymbol{\beta}$ & 0.591 & 0.138 & 0.0002 \\
$\boldsymbol{\lambda}$ & -0.98 & 0.149 & 0.0000 \\
$\boldsymbol{\eta}$ & 0.55 & 0.114 & 0.0000 \\
$\boldsymbol{\delta}$ & 0.493 & 0.096 & 0.0000 \\
\hline
\end{tabular}

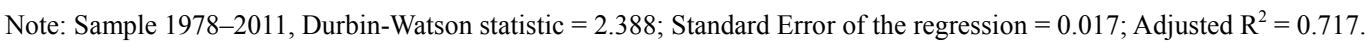

The short run marginal effect of remittances is about 1.5 , while it is only 0.6 for the trade balance. However, the long run marginal effect is approximately the same; 0.55 and 0.49 for respectively remittances and net exports.

\section{Conclusions and Policy Recommendations}

For Morocco, as many other developing countries, remittances inflows are an important source of financing development. It reduces, for example, the negative effect of trade deficit caused by energy and food imports especially in time of high oil and food prices.

This paper studies the flows of remittances from the major European sending countries, to check whether remittances could be a reliable source of external financing. I use the interdependencies between the Gross Domestic Products of major European host countries, namely; France, Italy, Spain, Belgium and Luxembourg, Netherlands, Germany and the United Kingdom, and Moroccan migrants' remittances via Vector Auto Regression models to assess the degree of dependency. This approach confirms that remittances are in general strongly pro-cyclical with the GDPs' in the most European host countries, especially countries severely affected by the financial crisis; Spain and Italy. The response functions used to evaluate the impact of GDP in the host countries on migrant remittances show all positive impacts. Remittances of Moroccan migrants in Belgium+Luxembourg, Germany and to some extent, the Netherlands, are resilient to GDP fluctuations of those countries. The deadline of amortizing and the magnitude vary across countries and shocks take about 3 to 5 years to fade away.

A scrutiny analysis of the current account shows an important role of the remittances flows in reducing the current account deficit, while these flows are shown to be procyclical to the European business cycle. This alters their role of cushioning negative effects of trade deficits especially in time of economic crises on the European Union. In fact, recent data shows a persistent increasing deficit over the period 2008-2012 after an impressive surplus in the period 2001-2006 despite the increasing trade balance deficit over this period pushed by soaring oil and food prices.

In order to assess the implications on the current account balance and confirm the important weight of 
remittances in the current account balance, I run two regressions relying remittances on the current account balance. We found that the balance could be enhanced by $0.75 \%$ for a one percent increase in remittances in the short run. The long run effect is also present as the two variables are cointegrated and has a coefficient of approximately 1.6. Considering marginal effect, an increase of $1 \$$ in remittances increases the change in net foreign asset by $1.5 \$$ in the short run, while it is only 0.6 as effect for net exports on change in net foreign assets. In the long run the marginal effect is about 0.55 and 0.50 respectively for remittances and net exports.

All these results should induce policy makers to develop actions attracting migrants to invest their savings in the home country. This will replace the lack of remittances in time of tough economic conditions in the hosting countries and strengthen linkages of the Diaspora with their home country. The investment profile and the political environment in the home country should be improved for such purposes. Actions should also increase cooperation with other labor hosting countries over the world to diversify the Moroccan migrant destinations.

\section{Acknowledgements}

I would like to thank, Doctors; Weshah Razzak, Ahmed Al Kawaz and the anonymous referees for their valuable comments.

\section{References}

Adams, R. H. Jr., \& John, P. (2005). Do international migration and remittances reduce poverty in developing countries? World Development, 33(10), 1645-1669. http://dx.doi.org/10.1016/j.worlddev.2005.05.004

Adams, R. H. Jr. (2006). International remittances and the household: Analysis and review of global evidence. Journal of African Economies, 15(2), 396-425. http://dx.doi.org/10.1093/jafeco/ej1028

Amuedo-Dorantes, C., \& Pozo, S. (2011). Remittances and Income Smoothing. American Economic Review, 101(3), 582-587. http://dx.doi.org/10.1257/aer.101.3.582

Anyanwu, J. C., \& Erhijakpor, A. E. O. (2010). Do international remittances affect poverty in Africa? African Development Review, 22(1), 51-91. http://dx.doi.org/10.1111/j.1467-8268.2009.00228.x

Ashley, R. A., \& Verbrugge, R. J. (2009). To difference or not to difference: A Monte Carlo investigation of inference in vector autoregression models. International Journal of Data Analysis Techniques and Strategies, 1(3), 242-274. http://dx.doi.org/1504/IJDATS.2009.024295

Barajas, A., Chami, R., Fullenkamp, C., \& Garg, A. (2010). The global financial crisis and workers' remittances to Africa: What's the damage? IMF working paper 10/24.

Bora, D. C., \& Sayan, S. (2008). Emerging market business cycles with remittance fluctuations. Board of Governors of the Federal Reserve System, International Finance Discussion Papers, 946, September 2008.

Bouhga-Hagbe, J. (2004). A theory of workers' remittances with an application to Morocco. IMF working paper 04/194.

Bugamelli, M., \& Paterno, F. (2011). Output growth volatility and remittances. Economica, 78, 480-500. http://dx.doi.org/10.1111/j.1468-0335.2009.00838.x

Chang, P., \& Sakata, S. (2007). Estimation of impulse response functions using long autoregression. Econometrics Journal, 10, 453-469. http://dx.doi.org/10.1111/j.1368-423X.2007.00216.x

Chari, V. V., Kehoe, P. J., \& McGrattan, E. R. (2005). A critique of structural VARs using business cycle theory. Federal Reserve Bank of Minneapolis Working Paper, 631.

De Haas, H. (2006). Migration, remittances and regional development in Southern Morocco. Geoforum, 37, 565580. http://dx.doi.org/10.1016/j.geoforum.2005.11.007

Frankel, J. (2009). Are bilateral remittances countercyclical? NBER Working Paper, 15419.

Ghosh, B. (2006). Migrants' remittances and development: Myths, rhetoric and realities. International Organization for Migration, Geneva, Switzerland.

Hoover, K. D. (2003). Some causal lessons from macroeconomics. Journal of Econometrics, 112, 121-125. http://dx.doi.org/10.1016/S0304-4076(02)00154-9

Lianos, T. P., \& Pseiridis, A. (2011). Remittances of immigrants in Greece. Review of Development Economics, 15(2), 340-355. http://dx.doi.org/10.1111/j.1467-9361.2011.00612.x

Lucas, R. E. B. (2007). Migration and rural development. Electronic Journal of Agricultural and Development Economics, 4(1), 99-122. Retrieved from http://ftp.fao.org/docrep/fao/010/ai193e/ai193e00.pdf 
Mookerjee, R., \& Roberts, J. (2011). Banking services, transaction costs and international remittance flows. Applied Economics Letters, 18, 199-205. http://dx.doi.org/10.1080/13504851003614146

Qin, D. (2011). Rise of VAR modeling approach. Journal of Economic Surveys, 25(1), 156-174. http://dx.doi.org/10.1111/j.1467-6419.2010.00637.x

Razzak, W. A., \& Bentour, E. M. (2013). Do developing countries benefit from foreign direct investments? An analysis of some Arab and Asian countries. Review of Middle East Economics and Finance, 9(3), 357-388. http://dx.doi.org/10.1515/rmeef-2012-0031

Ruiz, I., \& Vargas-Silva, C. (2010). Another consequence of the economic crisis: a decrease in migrants' remittances. Applied Financial Economics, 20, 171-182. http://dx.doi.org/10.1080/09603100903266450

Sayan, S. (2006). Business cycles and workers' remittances: How do migrant workers respond to cyclical movements of GDP at home? IMF Working Paper 06/52.

Sayan, S., \& Tekin-Koru, A. (2007). Business cycles and remittances: A comparison of the cases of Turkish workers in Germany and Mexican workers in the US. TOBB-ETU, Oregon State University, MPRA Paper 6030. Retrieved from http://mpra.ub.uni-muenchen.de/6030

Sayan, S., Tas, B. O., \& Yalta, Y. (2010). Cyclical behavior of Mexican remittances over the Mexican and the US business cycles. TOBB University of Economics and Technology working paper 1008. Retrieved from http://ikt.web.etu.edu.tr/RePEc/pdf/1008.pdf

Shaun, K. R., \& Gradzka, E. (2007). Do remittances to Latin America depend on the U.S. business cycle? IMF working paper, 07/273.

Sims, C. A. (1980) Macroeconomics and reality. Econometrica, 48(1), 1-48. http://dx.doi.org/10.2307/1912017

Sorensen, N. N. (2004). Migrant remittances as a development tool: The case of Morocco. Migration Policy Research, Working Papers, 2, June.

Yang, D. (2011). Migrant Remittances. Journal of Economic Perspectives, 25(3), 129-152. http://dx.doi.org/10.1257/jep.25.3.129

Zuniga, M. C. (2011). On the path to economic growth, do remittances help? Evidence from panel VARs. The Developing Economies, 49(2), 171-202. http://dx.doi.org/10.1111/j.1746-1049.2011.00128.x

\section{Notes}

Note 1. See Figure 3.

Note 2. See for examples; (Bouhga-Hagbe, 2004); Zuniga, 2011; Haas, 2006; Nyberg, 2004; Richard, 2005).

Note 3. Sayan (2006) investigated the assumption of the counter cyclicality with respect to GDP at home over 12 developing countries and found no support for this conjecture.

Note 4. Remittances recorded in the balance of payments are the cash flows actually observed, while a significant portion borrows unofficial paths and are not subsequently recorded. Studies have been made and believe that this part is also important and sometimes exceed those following official channels.

Note 5. Unpublished report of the Moroccan Ministry in charge of the Moroccan Immigrants (2010).

Note 6. Series of private transfers appearing in the balance of payments contain other elements not considered remittances (example: gifts, private donations). However, the share of those elements in the total is practically insignificant (about $8 \%$ to $10 \%$ over $2004-2010$ ). Therefore, the analysis remains valid.

Note 7. Remittances are also less volatile compared to the inflows of FDI. Furthermore, according to Razzak and Bentour (2013), FDI do not seem sufficiently benefit to MENA countries compared to developing Asia.

Note 8 . The share from EU is about $88.9 \%$ (Figure 4). The share of the sample on the total of EU is $96.8 \%$ (sum of the sample shares in Table 1). Then the share of the sample on the total is $88.9 \% * 96.8 \%=86.0 \%$.

Note 9. Table 3 shows positive correlations between GDP and remittances in levels and growths.

Note 10. For Morocco, valuation effects are about 3.5\% of GDP on the average over 1981-2011.

Note 11. We also tested unemployment and inflation rates impacts of the host countries on remittances but the results are not so robust to report.

Note 12. We only report responses of remittances and omit the impulses of GDPs as they are null and confirm 
what is reported in the causality tests. The direction of causality is one way from GDP to remittances.

Note 13. We can use directly the variable current account balance, but this is sometimes negative and the introduction of logarithm function is not permitted. However, the net foreign asset is positive over a relatively long period (1990-2011).

Note 14. Variables are all integrated of order one and residuals of the long run equation are stationary.

\section{Copyrights}

Copyright for this article is retained by the author(s), with first publication rights granted to the journal.

This is an open-access article distributed under the terms and conditions of the Creative Commons Attribution license (http://creativecommons.org/licenses/by/3.0/). 